\title{
Cloning of a Zinc-binding Cysteine Proteinase Inhibitor in Citrus Vascular Tissue
}

\author{
Danielle R. Ellis ${ }^{1}$ and Kathryn C. Taylor ${ }^{2,3}$ \\ Department of Plant Sciences, University of Arizona, 303 Forbes Building, Tucson, AZ 85721
}

AdDitional InDEX wORDs. defense proteins, Kunitz soybean proteinase inhibitor, Citrus jambhiri

\begin{abstract}
A partial cDNA (cvzbp-1) was cloned based on the N-terminal sequence of a citrus (Citrus L.) vascular Znbinding protein (CVZBP) previously isolated from vascular tissue (Taylor et al., 2002). CVZBP has homology to the Kunitz soybean proteinase inhibitor (KSPI) family. Recombinant protein produced using the cDNA clone inhibited the cysteine proteinase, papain. Metal binding capacity has not been reported for any other member of this family. CVZBP was present in leaves, stems, and roots but not seeds of all citrus species examined. However, CVZBP was present in germinating seeds after the cotyledons had turned green. Within four hrs after wounding, CVZBP was undetectable in the wounded leaf and adjacent leaves. It has been suggested that many members of the KSPI family serve a function in defense. However, the expression of the CVZBP is in direct contrast with those of KSPI members that were implicated in defense response. Though systemically regulated during wounding, we suggest that CVZBP is not a defense protein but rather may function in vascular development.
\end{abstract}

Overall, the role of proteinase inhibitors (PIs) is to negatively regulate proteolysis when physiologically or developmentally appropriate (Bode and Huber, 1992; Laskowski and Kato, 1980). Identification of specific interactions between proteinases and PIs in vivo is limited, however, especially in plant systems. Many PIs in plants are associated with response to abiotic stress or pathogen attack (Green and Ryan, 1972; Lopez et al., 1994; Peng et al., 1993; Saarikoski et al., 1996) and hence are often classed as stress or defense proteins.

Although evidences of their role as deterrents in plant protection are numerous (Boulter, 1989; Christeller et al., 1992; Klopfenstein et al., 1997; Mosolov and Shulgin, 1986; Tran et al., 1997), PIs may also have other functions in plants. Certainly there are Kunitz type soybean proteinase inhibitor (KSPI) (Kunitz, 1947) genes in potato (Solanum tuberosum L.) that are differentially regulated by development, and location (Gruden et al., 1997; Ishikawa et al., 1994; Yamagishi et al., 1991). Expressed at different stages in tuber development, the cathepsin D inhibitor and proteinase inhibitor II mRNAs were found in young leaves and tubers (Ishikawa et al., 1994).

It was suggested that PIs might function as storage proteins (Hattori et al., 1989; Kortt et al., 1989), because they account for $60 \%$ to $80 \%$ of total soluble protein in the tuberous root of sweet potato [Ipomoea batatas (L.) Lam.] and are localized to the vacuole in tuber cells (Hattori et al., 1985; Maeshima et al., 1985; Nakamura et al., 1993). However, Yeh et al. (1997) demonstrated that sporamin is a trypsin inhibitor, suggesting its role in tubers may be beyond that of storage. In tubers, defense against predation by sporamin seems likely, since these tissues have a high nutrient value and are key in propagation and plant survival. But it is certainly possible that sporamin may serve a developmental

Received for publication 6 May 2003. Accepted for publication 3 Apr. 2004. This work is a portion of a dissertation submitted by D.R. Ellis as partial fulfillment of requirements for doctor of philosophy degree. This work was partially supported by Arizona Citrus Research Council.

${ }^{1}$ Current address, Purdue Univ., Dept. of Horticulture and Landscape Architecture, West Lafayette, IN 47907.

${ }^{2}$ Current address, Dep. of Horticulture, Univ.of Georgia, Southeastern Fruit and Tree Nut Research Station, 21 Dunbar Rd., Byron, GA 31008

${ }^{3}$ To whom reprint requests should be addressed, Email address: kctaylor@uga. edu function in the quickly expanding parenchymal tissue of this modified stem tissue in sweet potato (Yeh et al., 1997). In other plant tissues, where levels of KSPIs are lower, their role seems less certain (Jongsma and Boulter, 1997). Not all PIs are induced by wounding or appear to be important for storage (Jofuku and Goldberg, 1989; Satoh, 1998). Thus, the participation of some PIs in normal developmental process must be considered.

There has been little research examining potential functions of PIs other than stress or defense, but it is apparent that proteinases act in a coordinated manner throughout the life of the plant. Examples have been documented during germination, pollen and tracheary element development, apoptosis, as well as stress response (Fukuda, 1997; Groover and Jones, 1999; Pennell and Lamb, 1997; Xu and Chye, 1999). Therefore, it seems likely that PIs could be involved in coordinating developmental processes. Solomon et al., (1999) found that programmed cell death (PCD) induced by oxidative stress preceded synthesis of a set of cysteine proteinases. Expression of a cysteine PI blocked PCD. A similar process was identified during development of tracheary elements (TE) in zinnia (Zinnia elegans L.) cell culture (Fukuda, 1997). Prior to autolysis a cysteine proteinase is expressed specifically in developing TEs (Minami and Fukuda, 1995), and addition of a cysteine PI, prior to secondary wall formation, prevents TE differentiation (Fukuda, 1997).

This paper contributes to a growing body of evidence that PI function is not limited to plant protection. We have isolated a cDNA clone of a previously isolated citrus vascular protein (CVZBP) (Taylor et al., 2002). CVZBP was detected in all citrus genotypes examined. It is a cysteine proteinase inhibitor and a member of the KSPI family. In contrast to other members of the KSPI family, CVZBP is not detectable in seeds and decreases in leaves in response to wounding. We suggest that CVZBP is not a defense protein but rather may function in vascular development.

\section{Materials and Methods}

Cloning AND SEQuencing of CDNA. Based on the previously determined N-terminal sequence of the CVZBP (Taylor et al., 2002), a degenerate PCR primer was designed as the forward or 5' PCR primer (5'-TCTGGATCCCAYGGNAAYAARGTNGARGC-3'). A Bam $\mathrm{Hl}$ restriction site was introduced into the 5' 
end of the $c v z b p$ primer to facilitate cloning. An oligo-dT primer with an $E c o$ Rl restriction site was the reverse primer. Citrus tissue was frozen in liquid nitrogen and ground finely using a mortar and pestle. RNA was isolated using the method of Ostrem et al., (1987). Total RNA was extracted two times with phenol:chloroform (1:1) and precipitated with $\mathrm{LiCl}$ (Ostrem et al., 1987). The resulting pellet was resuspended in diethylpyrocarbonate (DEPC) treated water. Ten micrograms of total RNA was treated with DNase I $\left(1 \mathrm{mg} \cdot \mathrm{mL}^{-1}\right)$ for $30 \mathrm{~min}$ at $37^{\circ} \mathrm{C}$, incubated for 10 min at $70{ }^{\circ} \mathrm{C}$ to inactivate the DNase, and extracted two times with 24 phenol : 24 chloroform : 1 isoamyl-alcohol (by volume). RNA was precipitated with 2.5 volumes of ethanol, washed with $70 \%$ ethanol, and resuspended in DEPC treated water. Reverse transcriptase-polymerase chain reaction (RT-PCR) was performed using $5 \mu \mathrm{g}$ of the DNase-treated RNA in a reaction mix that contained $100 \mu \mathrm{m}$ oligo-dT primer, $1.6 \mathrm{~mm}$ dNTPs, $1.5 \mathrm{~mm}$ $\mathrm{MgCl}_{2}$, and $200 \mathrm{U}$ of Superscript II (Gibco-BRL, Gaithersburg, Md.) following manufacturers' instructions. Subsequently, $2 \mu \mathrm{L}$ of the RT-PCR reaction was used as template in a PCR reaction containing $5 \mu \mathrm{M} \mathrm{cvzbp}$ primer and $10 \mu \mathrm{M}$ of oligo-dT primer. The reaction was initially heated to $95^{\circ} \mathrm{C}$ for $4 \mathrm{~min}$. Then 30 cycles of 2 min at $95^{\circ} \mathrm{C}, 1 \mathrm{~min}$ at $42^{\circ} \mathrm{C}$ and $2 \mathrm{~min}$ at $72^{\circ} \mathrm{C}$ were followed by a final incubation at $72{ }^{\circ} \mathrm{C}$ for $10 \mathrm{~min}$. The RT-PCR protocol was performed in the water-cooled Easy Cycler thermocycler (Ericomp, San Diego). The PCR reaction was electrophoresed in a $1.5 \%$ agarose gel and visualized with $0.5 \mathrm{~mL}$ ethidium bromide $\left(10 \mathrm{mg} \cdot \mathrm{mL}^{-1}\right)$. The PCR product was excised from the gel and the DNA eluted using a Qiaquick gel extraction kit (QIAGEN, Germantown, Md.). The eluted DNA was restricted with EcoRI and Bam HI and ligated into Bluescript SK+ (Stratagene, La Jolla, Calif.) plasmid that was digested with the same enzymes. The subsequent ligation reaction was transformed into XLI-Blue MRF (Stratagene) competent cells following manufacturer's instructions. Sequencing was performed at the Univ. of Arizona Macromolecular Structure facility using the Biosystems DyePrimer cycle sequencing protocol and automated sequencing.

SDS-PAGE ELECTROPHORESIS AND IMMUNOBLOTTING. Protein was extracted from citrus (Citrus macrophylla Wester) tissue as previously reported (Taylor and Geitzenauer, 1998) and quantified using the Bradford protein assay kit (BioRad, Hercules, Calif.) (Bradford, 1976) to facilitate equal gel loading in several experiments described herein. Protein samples were applied to $12 \%$ polyacrylamide gels at total protein levels noted for each experiment described below. Electrophoresis was carried out in a pH 8.3 Laemmli buffer system (Laemmli, 1970). Gels were stained with Coomassie Brilliant Blue $\mathrm{R}$ in 5 water : 1 acetic acid : 5 methanol (by volume), giving further evidence of equivalent protein loading in experiments.

For immunoblot analysis the proteins were transferred to poly(vinylidene diflouride) membrane (Hybond-P; Amersham Pharmacia Biotech, Arlington Heights, Ill.) in Towbin's buffer (Towbin et al., 1979). Electrotransfer was accomplished with the Bio-Rad Mini Trans-Blot apparatus after $1 \mathrm{~h}$ at $80 \mathrm{~V}$. Blots were blocked overnight in $1 \%$ bovine serum albumin in TBST (10 mu Tris-Cl, pH 8.0, 150 mu NaCl, 0.05\% Tween-20). Detection was performed by incubating blots in a 1:1000 dilution of anti-CVZBP rabbit serum in TBST followed by incubation in a 1:200 dilution of alkaline phosphatase labeled goat anti-rabbit serum (Sigma, St. Louis) in TBST. Blots were developed by the method of King et al. (1985).

EXPRESSION OF CVZBP IN CITRUS ORGANS AND SPECIES. Seedlings of three commercially used citrus rootstocks the clonal rootstock, 'Troyer' [Poncirus trifoliata (L.) Raf. x Citrus sinensis L.] and two seedling rootstocks, sour orange [Citrus aurantium L.) and macrophylla\} and one lemon cultivar [Citrus limon (L.) Burm.f. cv. Eureka] were grown in the greenhouse until they were 2 months of age. The plants were harvested and divided into leaves, roots and stems. The root tissue was carefully washed with distilled water containing 1\% Tween-20 (Sigma) and then rinsed three times with distilled water. Proteins were extracted from each sample and $5 \mu \mathrm{g}$ of total protein was separated on a polyacrylamide gel and immunoblotted with three replications of the experiment.

EXPRESSION OF CVZBP IN SEEDS. Citrus seeds were removed from fruits of five citrus rootstocks: the seedling rootstocks rough lemon(Citrus jambhiri Lush.), volkameriana(Citrus volkameriana V. Ten. \& Pasq.), sour orange, macrophylla, a clonal rootstock ('Troyer'), and one lemon cultivar ('Eureka'). Pulp was removed from the seed surface and the seeds were air-dried. Seeds were frozen in liquid nitrogen, ground in a coffee grinder, and protein extracted. Then $20 \mu \mathrm{g}$ of total protein was separated on a $12 \%$ polyacrylamide gel and immunoblot analysis performed with two replicates of the experiment.

CVZBP EXPRESSION DURING GERMINATION. Seeds of macrophylla rootstock were imbibed in water, with aeration for $24 \mathrm{~h}$. After a sub-sample was taken and frozen, the remaining seeds were placed in petri dishes containing wet filter paper. Seeds were collected at two stages: 1) when cotyledons had turned green but no germination had occurred and 2) after radical emergence. Protein was extracted from dry seeds, imbibed seeds and seeds at stage 1 and 2 . Then $2.5 \mu \mathrm{g}$ of protein from each sample was separated on a $12 \%$ polyacrylamide gel and immunoblot analysis performed. This experiment was repeated twice.

Wounding EXPERIMENT. Initial wounding experiments were conducted to determine the best method to use for wounding (needle punctures, plier bites and scalpel cuts were assessed for effectiveness) and how long after wounding, changes in protein levels occurred in the wounded and adjacent leaves $(2,4$, and 6 $\mathrm{h}$ were assessed). Total protein levels determined by Bradford analysis (Bradford, 1976) and by silver stained gels (Morrissey, 1981) demonstrated that wounding by needle punctures gave the best results when assayed after $4 \mathrm{~h}$ without deference to the $\mathrm{Zn}$ binding protein considered in this report. Twenty fully expanded leaves of 2-year-old macrophylla rootstock seedlings, maintained in a greenhouse on the Univ. of Arizona campus, were wounded by needle punctures. Each leaf was on a separate branch with five leaves treated per seedling. Five punctures were made on each side of the midrib taking care to avoid any major veins. After $4 \mathrm{~h}$, the wounded leaves were collected along with the leaf immediately above them and the leaf immediately below. At the same time unwounded leaves from separate branches on the same trees were sampled as controls. Protein was extracted and immunoblot analyses performed with $20 \mu \mathrm{g}$ total protein. This experiment was repeated three times.

EXPRESSION AND PURIFICATION OF RECOMBINANT CVZBP. A fusion protein was produced which consisted of a $5^{\prime}$ histidine leader and the open reading frame of $c z b p-1$ in the pRSETA vector (Invitrogen, Carlsbad, Calif.). The resulting construct was transformed into Escherichia coli JM109. The selected recombinant plasmid was sequenced to ensure no mutations had occurred. Recombinant protein was produced following the manufacturer's instructions for the pRSET expression system. The culture was grown for $4 \mathrm{~h}$ after induction of recombinant protein expression. The cells were then pelleted and lysed following the protocol of 
Sambrook et al. (1989). The recombinant CVZBP was present in the bacterial pellet after lysis and was solubilized and purified using the Xpress protein purification system, denaturing purification protocol and probond Ni column (Invitrogen) following manufacturer's instructions.

CYSTEINE PROTEINASE INHIBITOR ASSAY. The capacity of recombinant CVZBP to inhibit cysteine proteinases was determined by the method of Abe et al. (1994) with modifications. Reactions contained $67 \mu \mathrm{L}$ of $0.25 \mathrm{M}$ sodium phosphate buffer $(\mathrm{pH} 6.0)$, with $2.5 \mathrm{~mm}$ EDTA, $25 \mathrm{~mm} \beta$-mercaptoethanol, $33.3 \mu \mathrm{L}$ of 1 mM papain, and either $1 \mu \mathrm{L}$ of $1 \mathrm{mg} \cdot \mathrm{mL}^{-1}$ cystatin in PBS, $1 \mu \mathrm{L}$ PBS (control), or the indicated amount of recombinant CVZBP in PBS, $\mathrm{pH}$ 7.0. The reactions were incubated for $5 \mathrm{~min}$ at $37^{\circ} \mathrm{C}$ then, $67 \mu \mathrm{L}$ of the substrate [ $1 \mathrm{~mm} N$-benzoyl-L-arginine-2-naphthylamide (BANA)] was added and the reaction was incubated at $37^{\circ} \mathrm{C}$ for $10 \mathrm{~min}$. The reaction was stopped by addition of $333 \mu \mathrm{L}$ of $2 \% \mathrm{HCl}$ in ethanol, then the color was developed by addition of $0.06 \%$ p-dimethylaminocinnamalydehyde in ethanol. Absorbance of the solution was determined at $540 \mathrm{~nm}$. Inhibitory capacity was determined by a decrease in the proteinase capacity of papain in hydrolyzed BANA as indicated by a decrease in $\mathrm{A}_{540}$. Each reaction was replicated three times.

\section{Results}

ISOLATION OF PARTIAL CDNA CLONE AND SEQUENCE ANALYSIS. A 712-base pair (bp) band was obtained from RT-PCR using degenerate primers based on the CVZBP protein sequence (Taylor et al., 2002). The nucleotide sequence and deduced amino acid sequence of the cDNA is shown in Fig. 1. The cDNA has an open reading frame of $549 \mathrm{bp}$. The first 19 deduced amino acid residues were $100 \%$ identical with the N-terminal amino acid sequence of CVZBP obtained by micro-sequencing (Taylor et al., 2002). There were two putative polyadenylation signals, one 20 bases upstream and one 103 bases upstream of the poly-A tail (Joshi, 1987). BLAST sequence homology search (Altschul et al., 1990) demonstrated that the deduced amino acid sequence of $c z b p-1$ had homology with members of the KSPI family (Fig. 2). Alignment of CVZBP with other members of the KSPI family with CLUSTAL W (Thompson et al., 1994) shows that the four cysteine residues that are absolutely conserved in this group were present in the CVZBP (Fig. 2). It had the highest identity (34\%) and similarity $(45 \%)$ with a trypsin inhibitor isolated from the latex of papaya (Carica papaya L.) fruit (Odani et al., 1996).

ExPRESSION OF CVZBP. Immunoblot analysis of leaf, stem and root tissue from seedlings of 'Eureka' lemon and three citrus rootstocks, 'Troyer', macrophylla, and sour orange, demonstrated that CVZBP was present in all tissues examined regardless of seedling type (Fig. 3). However, CVZBP content varied among seedlings. In addition, the anti-CVZBP serum recognized a second slightly larger band. This band may represent an additional member of this family present in citrus. Alternatively it might be a result of modification of a portion of the CVZBP by glycosylation similar to three other members of the KSPI family (Odani et al., 1996; Shimazaki et al., 1999; Socorro et al., 2002; Takahashi et al., 1990).

No CVZBP was detectable by immunoblot analysis in protein from seeds of any citrus species examined but was present in flower buds (Fig. 4). The lack of detectable CVZBP in seeds directly contrasts with the high levels of some other members of the KSPI family in seeds (Jofuku and Goldberg, 1989; Leah and Mundy, 1989; Odani et al., 1996). However, analysis of germinating seeds indicated that CVZBP was present after the cotyledons turned green in the germinating seeds and during emergence of the radical (Fig. 5). Increasing the amount of total protein used for western analysis might result in the detection of CVZBP in seeds. However, even if this did occur, the levels would be much lower than those present in the germinating seeds. It is possible that CVZBP could have a function in protection of the germinating seedlings. Alternatively, previous immunoblot analysis of dissected leaves supported vascular localization of CVZBP (Taylor et al., 2002) and may explain the appearance of CVZBP as the seedling developed. While previous research suggested vascular localization, this has not been confirmed and it is possible that CVZBP is present in previously untested tissue or in amounts that were not detectable.

In replicated experiments, protein levels of the CVZBP decreased in leaves in response to wounding (Fig. 6). Again this contrasts with other members of this family (Bradshaw et al., 1989; Gruden et al., 1997; Krizaj et al., 1993; Saarikoski et al., 1996; Yeh et al., 1997). The decrease in CVZBP in the leaf below the wounded leaf suggests that there is systemic regulation of CVZBP in response to wounding. Systemic regulation in response to wounding and jasmonic acid has been demonstrated for other members of the KSPI family (Gruden et al., 1997; Haruta et al., 2001; Kang et al., 2002).

EXPRESSION OF RECOMBINANT CVZBP AND PROTEINASE INHIBITION CAPACITY. A fusion protein was produced which consisted of a $5^{\prime}$ histidine leader and the open reading frame of $c z b p-1$. The fusion protein was purified using Ni affinity chromatography (Fig. 8). The CVZBP fusion protein was present primarily in the pellet after bacterial lysis (Fig. 7). However, it did not appear to be present in protein bodies as is often the case in bacterial expression systems. No protein bodies were visible in the bacterial pellet. The fusion protein was only maintained in soluble form in $8 \mathrm{~m}$ urea. Exposure to nondenaturing conditions resulted in cross-linkage of the protein, which was visible as immediate aggregation of the protein. With $100 \times$ dilution in nondenaturing buffer (PBS) containing $\mathrm{Zn}$ and $\beta$-mercaptoethanol, low concentrations of protein were solubilized with an efficiency of $15 \%$ and used for the proteinase inhibitor assays. The inability to solubilize large quantities of protein in the nondenaturing buffer prevented us from cleaving the polyhistidine leader from the fusion protein. This should be kept in mind when considering the results of the inhibition assays.

The CVZBP inhibited neither trypsin nor chymotrypsin (Ellis, 1998). However, it did have the capacity to inhibit the cysteine proteinase, papain (Fig. 8). Addition of $2 \mu \mathrm{g}$ of CVZBP to the proteinase assay reduced proteinase activity to $25 \%$ of total activity. Likewise, a similar degree of inhibition was obtained with the addition of $1 \mu \mathrm{g}$ of cystatin.

\section{Discussion}

A partial cDNA clone ( $c v z b p-1)$ was isolated based on the Nterminal amino acid sequence previously determined for CVZBP isolated from citrus vascular tissue (Taylor et al., 2002). The first 19 deduced amino acid residues were $100 \%$ identical with the N-terminal amino acid sequence of CVZBP obtained by microsequencing (Fig. 1). The deduced amino acid sequence contained four histidines and seven cysteines, the same number estimated in the amino acid composition of purified CVZBP (Taylor et al., 2002). The protein expressed from $c v z b p-1$ reacted with the CVZBP antibody and its size was consistent with that of the na- 


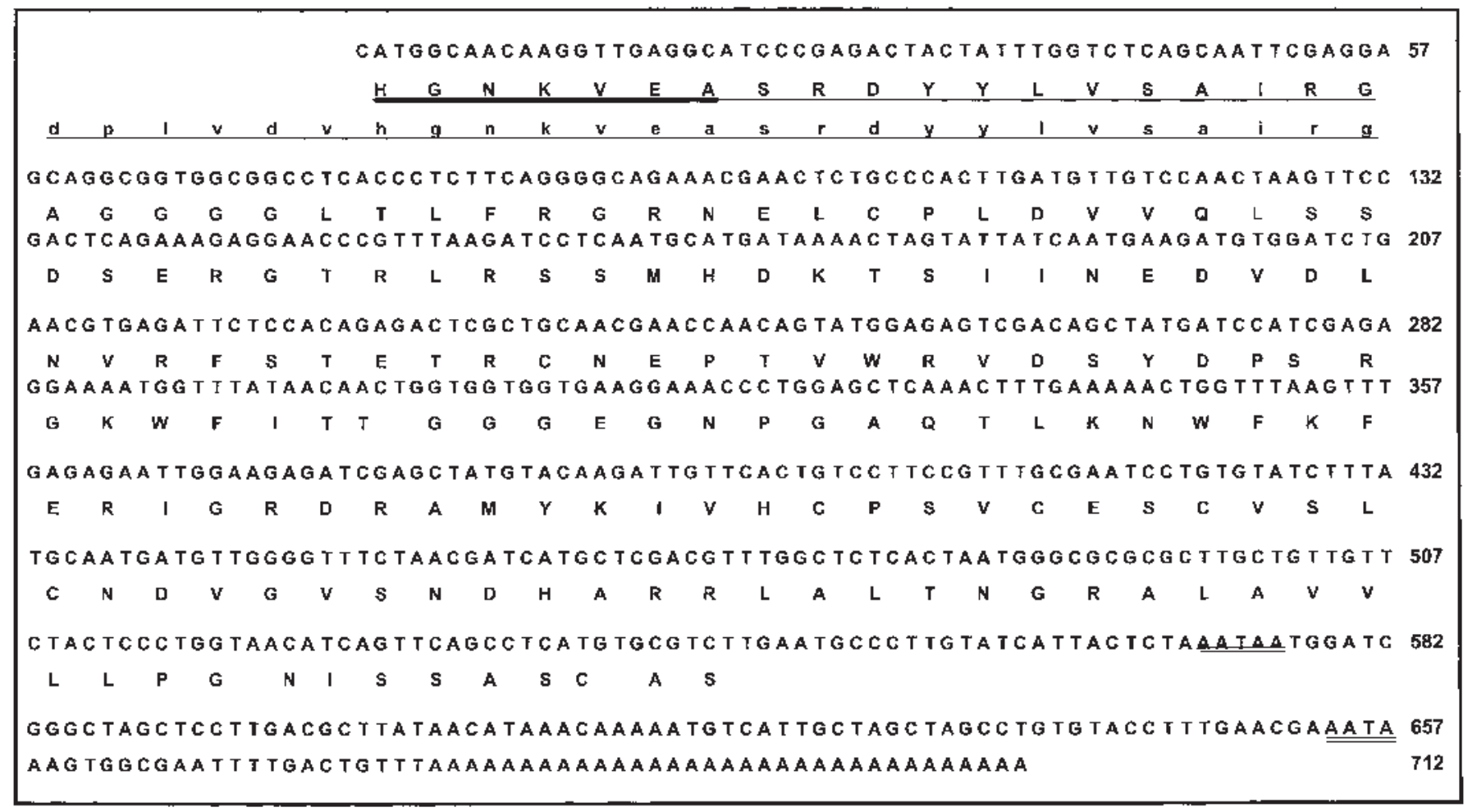

Fig. 1. The nucleotide sequence of the partial CVZBP cDNA clone $(c z b p-1)$ and its predicted amino acid sequence. The single underlined lowercase letters are the $\mathrm{N}$-terminal amino acid sequence of the CVZBP and the uppercase single underlined letters are the deduced amino acid sequence corresponding to the N-terminal sequence of the protein. The uppercase letters underlined with the thick line were the amino acid residues from which the degenerate $c v z b p$ primer, used in cloning, was derived. The double-underlined nucleotides are putative polyadenylation sites.

tive CVZBP, suggesting that this clone encodes the same protein previously purified from citrus (Taylor et al., 2002). The deduced amino acid sequence of the clone had identity with members of the KSPI superfamily (Fig. 2). The absence of a high degree of identity $(\approx 34 \%)$ by CVZBP with other KSPIs is not uncommon in members of this family since the functional domains of protease inhibitors are actually highly variable (Hill and Hastie, 1987 ) with identities ranging from $35 \%$ to $45 \%$. The N-terminal amino acid residue of the CVZBP as previously determined by $\mathrm{N}$-terminal amino acid sequencing was aspartic acid (Taylor et al., 2002). The lack of an $\mathrm{N}$-terminal methionine residue suggests that CVZBP has a propeptide that is removed after processing. The presence of propeptides was demonstrated for several members of the KSPI family (Gotor et al., 1995; Gruden et al., 1997; Ishikawa et al., 1994; Koide et al., 1997; Masuda et al., 1995; Souza et al., 1995; Spencer and Hodge, 1991; Yeh et al., 1997). The cDNA with an open reading frame of $549 \mathrm{bp}$ should encode 183 residue protein, weighing $\approx 22 \mathrm{kDa} \mathrm{M}_{\mathrm{r}}$ similar to other KSPIs (with $\mathrm{M}_{\mathrm{r}}$ between 19 and $25 \mathrm{kDa}$ ). This agrees with the previously estimated molecular weight for CVZBP of $22 \mathrm{kDa}$ based on gel electrophoresis (Taylor et al., 2002).

A key characteristic of members of the KSPI family is the presence of two disulfide bonds, one in the $\mathrm{N}$-terminal region and one at the C-terminus (Igeta et al., 1991). The cysteine residues that form these bonds are highly conserved and are present in CVZBP. The CVZBP contains two additional cysteine residues proximal to the conserved cysteines in the $\mathrm{C}$-terminus. These additional cysteines are present in some members of this family such as miraculin and the cacao seed specific protein (Cacao SP) but not all. In addition, this cysteine-rich domain, with an arrange- ment of $\mathrm{C}-\mathrm{X}_{3}-\mathrm{C}-\mathrm{X}_{2}-\mathrm{C}-\mathrm{X}_{4}-\mathrm{C}$, has identity with the $\alpha$-Cd-binding domain of metallothionein (De Miranda et al., 1990; Evans et al., 1990) and the iron-binding domain of Ferridoxin I (Berg, 1986). Two of these four residues were demonstrated to form a disulfide bond in miraculin (Igeta et al., 1991). Although some other SPI members contain additional cysteines, the presence of an additional disulfide bond is demonstrated only in miraculin. This suggests that in at least one member of this family the additional cysteines are cross-linked and this motif is not available to bind metal. However in the CVZBP, it is not improbable that $\mathrm{Zn}$ could be bound by these cysteines replacing the disulfide bonds, with a metal ion cross-linked between them as in the Cd-binding domain of metallothionein. It is possible this domain may contribute to the metal binding capacity previously reported for CVZBP(Taylor et al., 2002). The CVZBP is the first reported KSPI with apparent metal-binding capacity. However, metal-binding capacity in other KSPI family members cannot be eliminated as no such studies have been reported.

Identity of deduced amino acid sequences of $c v z b p-1$ with KSPIs leads to further speculation about possible function for CVZBP. The KSPI family is a diverse group of proteins that have several functions. It was suggested that many more fully characterized KSPIs serve a function(s) in plant defense (Green and Ryan, 1972; Ishikawa et al., 1994; Mosolov and Shulgin, 1986; Yeh et al., 1997). The apparent vascular location of the CVZBP certainly does not preclude this possible function. However, the lack of detectable levels of CVZBP in seeds and disappearance after wounding are in direct conflict with the notion of defense response. The increase in PIs in response to wounding has usually been determined by northern blot analysis and can occur in 


\begin{tabular}{|c|c|}
\hline CVZBP & - \\
\hline Papaya LPI & ----- \\
\hline Cocoa SP & MKTATAVVLLLFAFTS------KSYFFGV \\
\hline Miraculin & MKELTMLSLSFF-FVSGLLAAAANPRLSAA \\
\hline STI3 & $\begin{array}{c}\text { MKKTPIFFLFLFCAFTTSYLPSAIADF--- } \\
*\end{array}$ \\
\hline CVZBP & VSAIRGAGGGGLTLF-RGRNE--LCPLDVVQ \\
\hline Papaya LPI & VSAIWGAGGGGLTVYGPGNKK--KCPLSVVQ \\
\hline Cocoa SP & LSSISGAGGGGLALGRATGQS---CPEIVVQ \\
\hline Miraculin & VPVLRDHGGG-LTVSATTPNGTFVCPPRVVQ \\
\hline STI3 & $\begin{array}{c}\text { LSDITAFGG----IRAAPTGNERCPLTVVS } \\
*\end{array}$ \\
\hline CVZBP & IINEDVDLNVRF STETR---C--NEPTVWTRV \\
\hline Papaya LPI & IVFESVDLNVKF NITIN---C--NETTAWKV \\
\hline Cocoa SP & VVRVSTDVNIEFVPIRD-RLC--STSTVWRI \\
\hline Miraculin & VVRVSTDLNINESAFMP---CRWTSSTVWRI \\
\hline STI 3 & 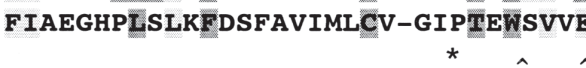 \\
\hline CVZBP & GAQTLKNWFKFERIGRD-RAMYKIVHCPSVC \\
\hline Papaya LPI & GFESTHSMFKIKKAGLP-FS-YKFHFCPSYP \\
\hline Cocoa SP & GPNTLCSWFKIEKAG-V-LG-YKFRFCPSV \\
\hline Miraculin & GPETISSWFKIEEFC-G-SGFYKLVFCPTVC \\
\hline STI3 & --DAMDGWFRLERVSDDEFNNYKLVFCPQQA \\
\hline CVZBP & EALTNGRALAVVLLPGNISS----ASCAS \\
\hline Papaya LPI & LILTND-AKEFVFIKTNR \\
\hline Cocoa SP & ZALS-DNEWAWMFKKASKTI----KQVVNAK \\
\hline Miraculin & 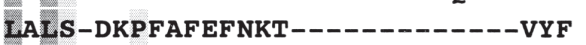 \\
\hline STI3 & LVVSKNKPLVVQFQKLDKESLAKKNHGLSRS \\
\hline
\end{tabular}

Fig. 2. CLUSTAL W alignment of deduced amino acid sequence of CVZBP and papaya latex proteinase inhibitor (papaya LPI), cocoa seed specific protein (Cocoa SP), miraculin and soybean trypsin inhibitor 3 (STI3). The first six amino acid residues of CVZBP were derived from direct sequencing of the protein. Gaps introduced to optimize alignment comparisons are designated by dashes. The dark shading indicates positions of amino acid identity and the light shading indicates conservative substitutions. The active site residue, arginine, of STI3 is underlined with a double line. The four conserved cysteines present in the KSPI family are indicated by the symbol,$^{*}$, above them. The two cysteines present in some KSPI family members are indicated by the symbol,, , above them.

as little as 45 min (Suh et al., 1991; Xu et al., 2001; Yeh et al., 1997). The difference between our results and those previously reported could result from the measurement of protein levels rather than mRNA levels. However, Haruta et al. (2001) found that both mRNA and protein levels of a KSPI increased in aspen (Populus tremuloides Michx.) in response to wounding. The disappearance of CVZBP in response to wounding might occur because its presence inhibits a wound response.

There are KSPIs that either have not been characterized functionally or do not appear to be important in plant defense (Fukuda, 1997; Masuda et al., 1995; Pennell and Lamb, 1997). It has been suggested that because some members of this family are expressed developmentally, perhaps some of them have a function in the progress of plant/organ development.

Several investigators (Habu et al., 1996; Jofuku and Goldberg, 1989; Sakata et al., 1997; Solomon et al., 1999; Xu et al., 2001) have suggested that proteinase inhibitors might regulate proteolytic activities in an organ or tissue specific and temporally regulated manner. Although not reported in vascular tissue, Jofuku and Goldberg (1989) reported that one of three similar developmentally expressed genes, KTI3, encoded a kunitz protease inhibitor that appeared to function in soybean embryos, but suggested that the KTI1 and KTI2 genes did not encode proteins with proteinase inhibitory function. Sakata et al. (1997) identified developmentally regulated genes that are members of the KSPI family in winged bean [Psophocarpus tetragonolobus (L.) DC].
Habu et al. (1996) reported the localization of a member of the KSPI family (WCI-3) to the phloem of winged bean. He suggested that proteinase inhibitors might be important during the development of vascular cell types, and further that one function of WCI-3 might be the regulation of proteolytic activity during sieve tube element differentiation. If proteinase inhibitory function is involved in the regulation of phloem tissue development, is it also possible in xylem?

Could CVZBP function in differentiation of vascular tissues? Fukuda (1996) and others report the involvement of proteinases in TE development (Groover and Jones, 1999; Iliev and Savidge, 1999; Minami and Fukuda, 1995). Would proteinase inhibitors complement proteinase activity as a participant in coordinated aspects of development?

Comparisons were made by Pennell and Lamb (1997) between apoptosis in animals and PCD in plants, including TE development. In animal systems, proteinases such as members of the interleukin-1ß-converting enzyme family and cysteine proteinase are participants in the process of apoptosis (Martin and Green, 1995). Pennell and Lamb (1997) suggested that the cysteine proteinases identified in developing TE might have a homologous role to proteinases in animal apoptosis. Further, addition of cysteine PIs to carp cell cultures was demonstrated to inhibit virus induced apoptosis (Bjoerklund et al., 1997). Finally, a group of serine PIs that modulate proteolytic pathways involved in regulation of apoptosis was identified in mammalian systems (Dickinson et 


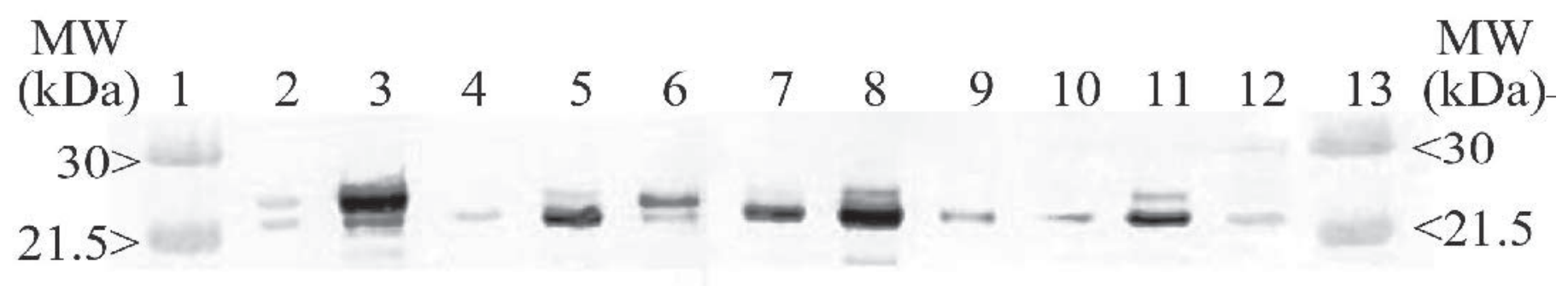

Fig. 3. Immunoblot analysis for CVZBP in protein from leaves, roots and stems of seedlings of four Citrus species. Each lane contains $5 \mu \mathrm{g}$ of total protein. Lanes 1 and 13: marker, lane 2: Troyer rootstock roots, lane 3: Troyer rootstock leaves, lane 4: sour orange rootstock roots, lane 5: sour orange rootstock stems, lane 6: sour orange rootstock leaves, lane 7: 'Eureka' lemon roots, lane 8: 'Eureka' lemon stems, lane 9: 'Eureka' lemon leaves, lane 10: macrophylla rootstock roots, lane 11: macrophylla rootstock stems, and lane 12: macrophylla rootstock leaves.

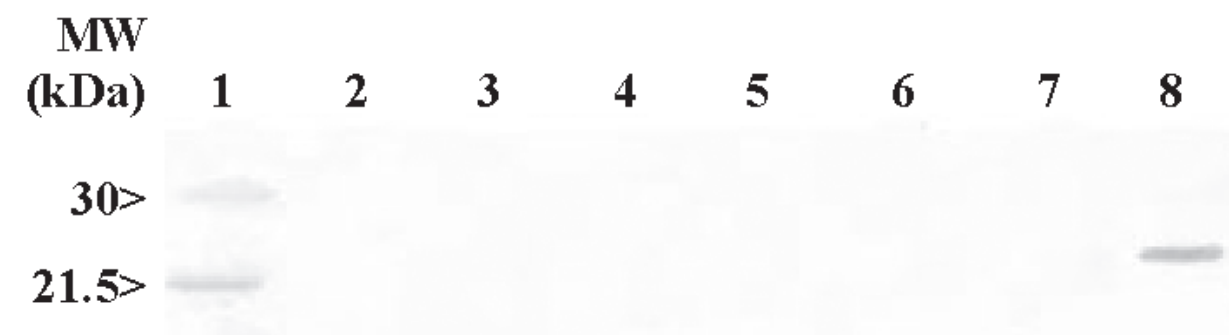

Fig. 4. Immunoblot analysis of CVZBP in seeds from four citrus rootstocks and one lemon scion cultivar ('Eureka'). Each lane contains $20 \mu \mathrm{g}$ of total protein. Lane 1: marker, lane 2: rough lemon rootstock, lane 3: volkameriana rootstock, lane 4: sour orange rootstock, lane 5: Eureka lemon, lane 6: macrophylla rootstock, lane 7: 'Troyer' rootstock, lane 8: ‘Eureka' lemon flower buds.

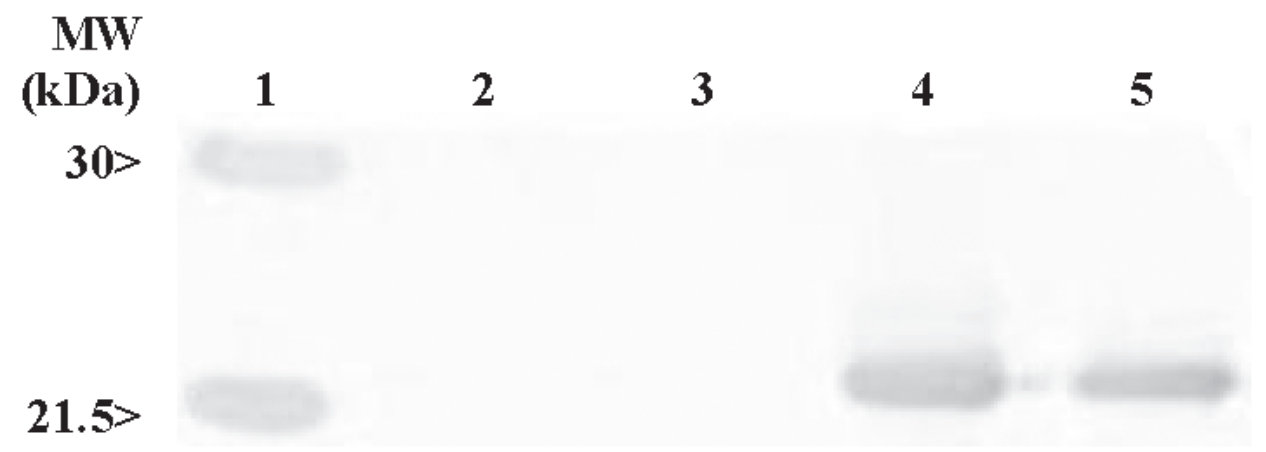

Fig. 5. Immunoblot analysis of CVZBP in germinating macrophylla rootstock seeds. Each lane contains $2.5 \mu \mathrm{g}$ of total protein. Lane 1: marker, lane 2: dry seeds, lane 3: seed after imbibition for $24 \mathrm{~h}$, lane 4: seed before germination with green cotyledons, lane 5: germinating seed at radical emergence.

al, 1998; Jenson, 1997). The participation of PIs in regulation of apoptosis in animal systems offers further support for the potential involvement of PIs in regulation of PCD processes in plants, such as that associated with TE development in the xylem. Further research will be required to test the hypothesis that CVZBP is involved in controlling timing or location of differentiation of TEs. Altering expression of this protein, determination of time and location of expression in conjunction with identification of in vivo substrates will be necessary to further elucidate any function that CVZBP may have in xylem development.

\section{Literature Cited}

Abe, M., K. Abe, K. Iwabuchi, C. Domoto, and S. Arai. 1994. Corn cystatin I expressed in Escherichia coli: Investigation of its inhibitory profile and occurrence in corn kernels. J. Biochem. 116:488-492.

Altschul, S.F., W. Gish, Q. Miller, E.W. Myers, and D.J. Lipman. 1990.
Basic local alignment search tool. J. Mol. Biol. 215:403-410.

Berg, J.M. 1986. Potential metal-binding domains in nucleic acid binding proteins. Science 232:485-486.

Bjoerklund, H.V., T.R. Johansson, and A. Rinne. 1997. Rhabdovirusinduced apoptosis in a fish cell line is inhibited by a human endogenous acid cysteine proteinase inhibitor. J. Virol. 7:5658-5662.

Bode, W. and R. Huber. 1992. Natural protein inhibitors and their interaction with proteinases. Eur. J. Biochem. 204:433-451.

Boulter, D. 1989. Genetic engineering of plants for insect resistance. Outlook on Agr. 18:2-6.

Bradford, M.M. 1976. A rapid method for quantification of microgram quantities of protein utilizing the principle of protein dye binding. Anal. Biochem. 22:248-254

Bradshaw, H.D., Jr., J.B. Hollick, T.J. Parsons, H.R.G. Clark, and M.P. Gordon. 1989. Systemically wound-responsive genes in poplar trees encode proteins similar to sweet potato sporamins and legume Kunitz trypsin inhibitors. Plant Mol. Biol. 14:51-59.

Christeller, J.T., W.A. Laing, N.P. Markwick, and E.P. Burgess. 1992. 


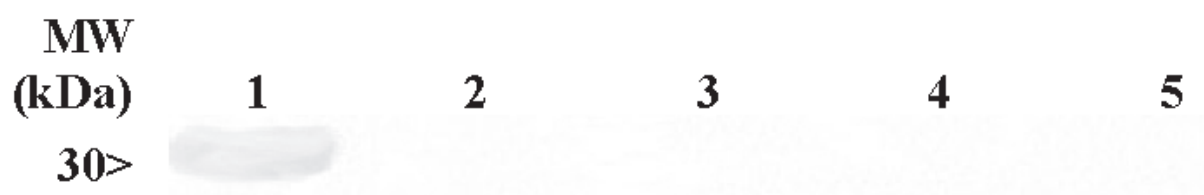

\section{5>}

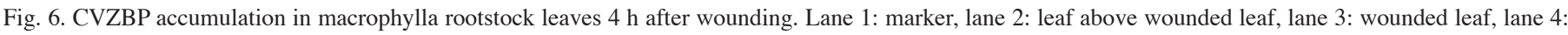
leaf below wounded leaf, lane 5: unwounded control leaf.

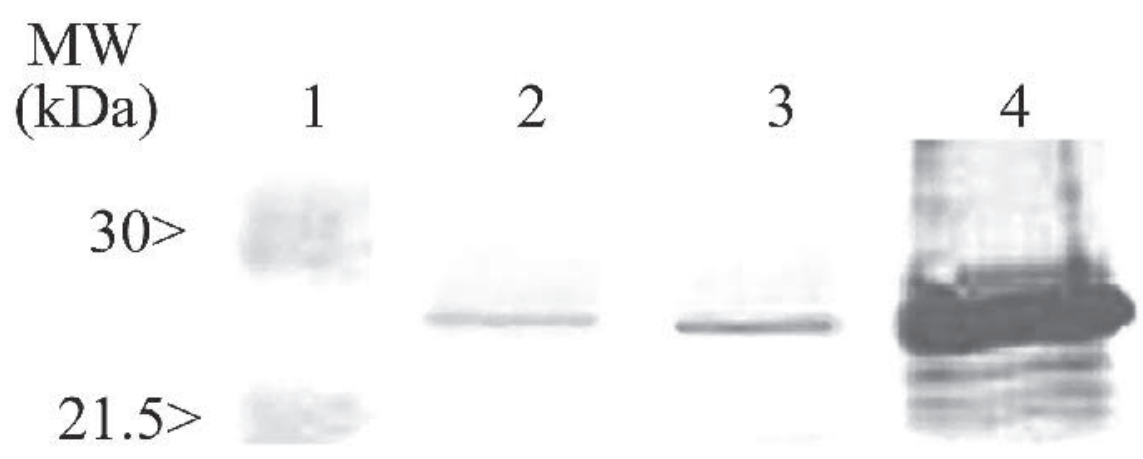

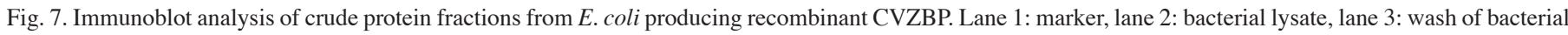
pellet, and lane 4: protein from bacterial pellet solubilized in $8 \mathrm{~m}$ urea.

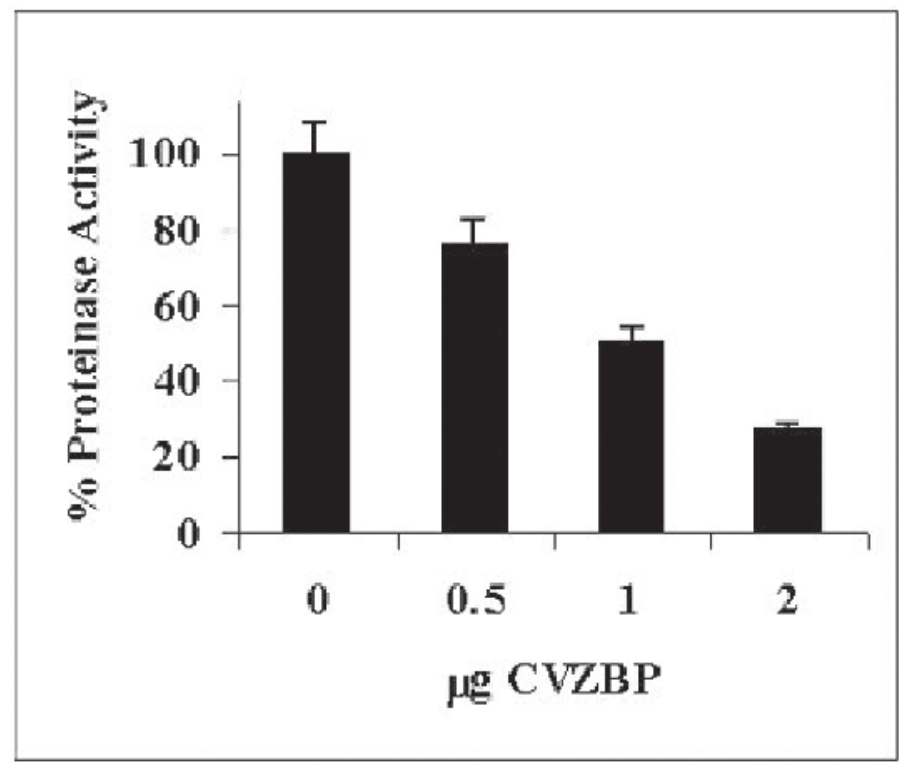

Fig. 8. Inhibition of the cysteine proteinase, papain, by recombinant CVZBP.

Midgut proteinase activities in 12 phytophagous lepidopteran larvae: Dietary and proteinase inhibitor interactions. Insect Biochem. Mol. Biol. 22:735-746.

De Miranda, J.R., M.A. Thomas, D.A. Thurman, and A.B. Tomsett 1990. Metallothionein of cDNAs associated with tracheary element differentiation in cultured zinnia cells. Plant Physiol. 103:815-821.

Dickinson, J.L., B.J. Norris, P.H. Jenson, and T.M. Antalis. 1998. The
C-D interhelical domain of the serpin plasminogen activator inhibitortype 2 is required for protection from TNF-alpha induced apoptosis. Cell Death Differentiation 5:163-171.

Ellis, D.R. 1998. Characterization of a citrus vascular specific zinc binding cysteine proteinase inhibitor. PhD Diss. Abstr., Univ. of Arizona, Tucson.

Evans, I.M.,L.N. Gatehouse, J.A. Gatehouse, N.J. Robinson, and R.R.D. Croy. 1990. A gene from pea (Pisum sativum L.) with homology to metallothionein genes. FEBS Lett. 262:29-32.

Fukuda, H. 1996. Xylogenesis: Initiation, progression, and cell death. Annu. Rev. Physiol. Plant Mol. Biol. 47:299-325.

Fukuda, H. 1997. Tracheary element differentiation. Plant Cell 9:1147-1156.

Gotor, C., J.A. Pintor-Toro, and L.C. Romero. 1995. Isolation of a new member of the soybean Kunitz-type proteinase inhibitors. Plant Physiol. 107:1015-1016.

Green, R.T. and C.A. Ryan. 1972. Wound-induced proteinase inhibitor in plant leaves: A possible defense mechanism against insects. Science 175:776-777.

Groover,A. and A.M. Jones. 1999. Tracheary element differentiation uses a novel mechanism coordinating programmed cell death and secondary cell wall synthesis. Plant Physiol. 119:375-384.

Gruden, K., B. Strukelj, M. Ravniker, M. Poljsak-Prijatelj, I. Mavric, J. Brzin, J. Pungercarn, and I. Kregar. 1997. Potato cysteine proteinase inhibitor gene family: Molecular cloning, characterization and immunocytochemical localization studies. Plant Mol. Biol. 34:317-323.

Habu, Y., H. Fukushima, Y. Sakata, H. Abe, and R. Funada. 1996. A gene encoding a major kunitz proteinase inhibitor of storage organs of winged bean is also expressed in the phloem of stems. Plant Mol. Biol. 32:1209-1213.

Haruta, M., I.T. Major, M.E. Christopher, J.J. Patton, and C.P. Constabel. 2001. A kunitz trypsin inhibitor gene family from trembling aspen (Populus tremuloides Michx.): Cloning, functional expression, and 
induction by wounding and herbivory. Plant Mol. Biol. 46:347-359.

Hattori, T., T. Nakagaw, M. Maeshima, K. Nakamura, and T. Asahi. 1985. Molecular cloning and nucleotide sequence of cDNA for sporamin, the major soluble protein of sweet potato tuberous roots. Plant Mol. Biol. 5:313-320.

Hattori, T., N. Yoshida, and K. Nakamura. 1989. Structural relationship among the members of a multigene family coding for the sweet potato tuberous root storage protein. Plant Mol. Biol. 13:563-572.

Hill, R.E. and N.D. Hastie. 1987. Accelerated evolution on the reactive center regions of serine proteinase inhibitors. Nature 326:96-99.

Igeta, H., Y. Tamura, K. Nakaya, Y. Nakamura, and Y. Kurihara. 1991. Determination of disulfide array and subunit structure of taste-modifying protein, miraculin. Biochem. \& Biophys. Acta 1079:303-307.

Iliev, I. and R. Savidge. 1999. Proteolytic activity in relation to seasonal cambial growth and xylogenesis in Pinus banksiana. Phytochemistry 50:953-960.

Ishikawa, A., S. Ohta, K. Matsuoka, T. Hattori, and K. Nakamura. 1994. A family of potato genes that encode kunitz-type proteinase inhibitors: Structural comparisons and differential expression. Plant Cell Physiol. 35:303-312.

Jenson, P.H. 1997. Structure and function of plasminogen activator inhibitor-2: An intracellular serine proteinase inhibitor modulating apoptosis. Intl. J. Oncology 11:557-570.

Jofuku, D.K. and R.B. Goldberg. 1989. Kunitz trypsin inhibitor genes are differentially expressed during the soybean life cycle and in transformed tobacco plants. Plant Cell 1:1079-1093.

Jongsma, M.A. and C. Boulter. 1997. The adaptation of insects to plant proteinase inhibitors. J. Insect Physiol. 43:885-895.

Joshi, C.P. 1987. Putative polyadenylation signals in nuclear genes of higher plants: A compilation and analysis. Nucleic Acids Res. 15:9627-9640.

Kang, S.G., J.H. Choi, and S.G. Suh. 2002. A leaf-specific 27 kDa protein of potato Kunitz-type proteinase inhibitor is induced in response to abscisic acid, ethylene, methyl jasmonate, and water deficit. Mol. Cells 28:144-147.

King, S.M., T. Otter, and G.B. Witman. 1985. Characterization of monoclonal antibodies against Chlamaydomonas flagellar dyneins by high resolution protein blotting. Proc. Natl. Acad. Sci. USA 82:4717.

Klopfenstein, N.B., K.K. Allen, F.J. Avila, S.A. Heuchelin, J. Martinez, R.C.Carmen, R.B. Hall, E.R. Hart, and H.S. McNabb. 1997. Proteinase inhibitor II gene in transgenic poplar: Chemical and biological assays. Biomass \& Bioenergy 12:299-311.

Koide, Y., H. Hirano, K. Matsuoka, and K. Nakamura. 1997. The Nterminal propeptide of the precursor to sporamin acts as a vacuoletargeting signal even at the $\mathrm{C}$ terminus of the mature part in tobacco cells. Plant Physiol. 114:863-870.

Kortt, A.A., P.M. Strike, J. Jersey. 1989. Amino acid sequence of a crystalline seed albumin (winged bean albumin-1) from Psophocarpus tetragonolobus (L.) DC: Sequence similarity with Kunitz-type seed inhibitors and 7S storage globulins. Eur. J. Biochem. 181:403-408.

Krizaj, I., M. Drobnie-Kosorok, J. Brizin, R. Jerala, and V. Turk. 1993. The primary structure of inhibitor of cysteine proteinases from potato. FEBS Letters 333:15-20.

Kunitz, M.J. 1947. Isolation of a crystalline protein compound of trypsin and of soybean trypsin-inhibitor. Gen. Physiol. 30:311-320.

Laemmli, U.K. 1970. Cleavage of structural proteins during the assembly of the head of bacteriophage T4. Nature 227:68-685.

Laskowski, M. and I. Kato. 1980. Protein inhibitors of proteinases. Ann. Rev. Biochem. 49:593-626.

Leah, R. and J. Mundy. 1989. The biofunctional a-amylase/subtilisin inhibitor of barley: Nucleotide sequence and patterns of seed-specific expression. Plant Mol. Biol. 12:673-682.

Lopez, F., G. Vansuyt, P. Fourcroy, and F. Casse-Delbart. 1994. Accumulation of a 22-kDa protein and its mRNA in the leaves of Raphanus sativus in response to salt stress or water deficit. Physiol. Plant. 91:605-614.

Maeshima, M., T. Sasak, and T. Asahi. 1985. Characterization of major proteins in sweet potato tuberous roots. Phytochemistry 24:1899-1902.
Martin, S.J. and D.R. Green. 1995. Proteinase activation during apoptosis: Death by a thousand cuts? Cell 82:349-352.

Masuda, Y., S. Nirasaw, K. Nakaya, and T. Kurihara. 1995. Cloning and sequencing of a cDNA encoding and taste-modifying protein, miraculin. Gene 161:175-177.

Minami, A. and H. Fukuda. 1995. Transient and specific expression of a cysteine endopeptidase during autolysis in differentiating tracheary elements from zinnia mesophyll cells. Plant Cell Physiol. 36:1599-1606.

Morrissey, J.H. 1981. Silver stain for proteins in polyacrylamide gels: A modified procedure with enhanced uniform sensitivity. Anal. Biochem. 117:307-310.

Mosolov, V.V. and M.N. Shulgin. 1986. Protein inhibitors of microbial proteinases from wheat, rye and triticale. Planta 167:595-600.

Nakamura, K., K. Matsuota, F. Mukumoto, and N. Watanabe. 1993. Processing and transport to the vacuole of a precursor to sweet potato sporamin in transformed tobacco cell line BY-2. J. Expt. Bot. 44:331-338.

Odani, S., Y. Yokokawa, H. Takeda, S. Abe, and S. Okani. 1996. The primary structure and characterization of carbohydrate chains of the extracellular glycoprotein proteinase inhibitor from latex of Carica papaya. Eur. J. Biochem. 241:77-82.

Ostrem, J.A., S.W. Olsen, J.M. Schmit, and H.J. Bohnert. 1987. Salt stress increases the level of translatable mRNA for phosphoenolpyruvate carboxylase in Mesembryanthemum chrystalinum. Plant Physiol. 84:1270-1275.

Peng, L., J.H. Bradbury, B.C. Hammer, and D.C. Shaw. 1993. Comparison of amino acid sequences of trypsin inhibitors from taro (Colocasia esculanta), giant taro (Alocasia macrorrhiza) and swamp taro (Cyrtosperma chamissonis). Biochem. Mol. Biol. Intl. 31:73-81.

Pennell, R.I. and C. Lamb. 1997. Programmed cell death in plants. Plant Cell 9:1157-1168.

Saarikoski, P., D. Clapham, and S. von Arnold. 1996. A wound-inducible gene from Salix viminalis coding for a trypsin inhibitor. Plant Mol. Biol. 31:465-478.

Sakata, Y., Y. Chiba, H. Fukushima, N. Matsubara, Y. Habu, S. Naito, and T. Ohno. 1997. The RY sequence is necessary but not sufficient for the transcription activation of a winged bean chymotrypsin inhibitor gene in developing seeds Plant Mol. Biol. 34:191-197.

Sambrook, J., E.F. Fritsch, and T. Maniatis. 1989. Molecular cloning: A laboratory manual, Cold Spring Harbor Laboratory, Cold Spring Harbor, N.Y.

Satoh, S. 1998. Function of the cell wall in the interactions of plant cells: Analysis using carrot cultured cells. Plant Cell Physiol. 39:361-368.

Shimazaki, A., Y. Makino, K. Omichi, S. Odani, and S. Hase. 1999. A new sugar chain of the proteinase inhibitor from latex of Carica papaya. J. Biochem. 125:560-565.

Socorro M.D., M. Cavalcanti, M.L.V. Oliva, H. Fritz, M. Jochum, R. Mentele, M. Sampaio, L.C.B.B. Coelho, I.F.C. Batisia, and C.A.M. Sampaio. 2002. Characterization of a kunitz trypsin inhibitor with one disulfide bridge purified from Swartzia pickellii. Biochem. Biophys. Res. Comm. 291:635-639.

Solomon, M., B. Belenghi, M. Delledonne, E. Menachem, and A. Levine. 1999. The involvement of cysteine proteases and protease inhibitor genes in the regulation of programmed cell death in plants. Plant Cell 11:431-443.

Souza, E.M., K. Mizuta, M.U. Samoaio, and C.A.M. Sampaio. 1995. Purification and partial characterization of a Schizolobium parahyba chymotrypsin inhibitor. Phytochemistry 39:521-525.

Spencer, M.E. and R. Hodge. 1991. Cloning and sequencing of the cDNA encoding the major albumin of Theobroma cacao. Planta 183:528-535.

Suh S.G., W.J. Stiekema, and D.J. Hannapel. 1991. Proteinase-inhibitor activity and wound-inducible gene expression of the 22-kDa potatotuber proteins. Planta 184:423-430.

Takahashi, N., H. Hitotsuya, H. Hanzawa, Y. Arata, and Y. Kurihara. 1990. Structural study of asparagine-linked oligosaccharide moiety of taste-modifying protein, miraculin J. Biol. Chem. 265:7793-7798. 
Taylor, K.C., D.R. Ellis, and L. Paiva. 2002. Purification of a zinc binding protein from xylem of Citrus jambhiri. J. Amer. Soc. Hort. Sci. 127:718-723.

Taylor, K.C. and H.C. Geitzenauer. 1998. Comparison of citrus blight and macrophylla decline disorders. J. Amer. Soc. Hort. Sci. 123:357-360.

Thompson, J.D., D.G. Higgins, and T.J. Gibson. 1994. CLUSTAL W: improving the sensitivity of progressive multiple sequence alignment through sequence weighting, position-specific gap penalties and weight matrix choice. Nucleic Acids Res. 22:4673-4680.

Towbin, H., T. Staehlin, and T. Gordon. 1979. Electrophoretic transfer of proteins from polyacrylamide gels to nitrocellulose sheets. Proc. Natl. Acad. Sci. USA 76:4350-4354.

Tran, R., T.M. Cheesbrough, and R.W. Keickhefer. 1997. Plant proteinase inhibitors are potential anticereal aphid compounds. J. Econ. Entomol. 90:1672-1677.

Xu, F.X. and M.L. Chye. 1999. Expression of cysteine proteinase during developmental events associated with programmed cell death in brinjal. Plant J. 17:321-327.

Xu, Z.F., W.Q. Qi, X.Z. Ouyang, E. Yeung, and M.L. Chye. 2001. A proteinase inhibitor II of Solanum americanum is expressed in phloem. Plant Mol. Biol. 47:727-738.

Yamagishi, K., C. Mitsumori, and Y. Kikuta. 1991. Nucleotide sequence of a cDNA encoding the putative trypsin inhibitor in potato tuber. Plant Mol. Biol. 17:287-288.

Yeh, K., J. Chen, M. Lin, Y. Chen, and C. Lin. 1997. Functional activity of sporamin from sweet potato (Ipomoea batatas Lam.): A tuber storage protein with trypsin inhibitory activity. Plant Mol. Biol. 33:565-570. 